\title{
EFFECT OF WEATHERING GRADE ON MECHANICAL PROPERTIES OF ROCKS FROM RANAU, SABAH
}

Hennie Fitria Wulandary Soehady Erfen ${ }^{1,2^{*}}$

\author{
${ }^{1}$ Geology Programme, Faculty of Science and Natural Resources Universiti Malaysia Sabah, Jalan UMS, 88400 Kota Kinabalu, Sabah \\ ${ }^{2}$ Natural Disaster Research Centre, Universiti Malaysia Sabah \\ *Corresponding Author Email: henniefs@ums.edu.my
}

This is an open access article distributed under the Creative Commons Attribution License, which permits unrestricted use, distribution, and reproduction in any medium, provided the original work is properly cited

\section{ARTICLE DETAILS}

\section{Article History:}

Received 2 July 2017

Accepted 4 October 2017

Available online 1 November 2017

Keywords:

bacillus pastteurii, calcite precipitation, compression, temperature, wind erosion resistance

\section{ABSTRACT}

A study of effect of weathering grade on mechanical properties of rocks have been conducted on selected rock samples from Crocker Formation, Trusmadi Formation and peridotite on weathering grade II to V. The objective is to study on how weathering grade does able to alter the microfabric of rocks which affect to its mechanical properties. The increment of weathering grade does increase the percentage of microfractures, porosity and clay minerals formation which became the factor of rock weakness through the reduction of density, hardness and strength of the rock. By understanding this, it is easier to predict and estimate the strength of rock slope and slope failure occurrences. As conclusion, sandstones from Trusmadi Formation is the strongest compared to sandstones from Crocker Formation and peridotite with $187.06-2.48 \mathrm{MPa}, 83.15-0.43 \mathrm{MPa}$ and $125.27-20.92 \mathrm{MPa}$ throughout weathering grade II to $\mathrm{V}$, respectively.

\section{INTRODUCTION}

Weathering is defined as the process of changing the physical and chemical properties of rock's materials that depend on the environmental condition and its properties before weathered as residual soils. Weathering grade can be classified from Grade II (slightly weathered) to Grade V (completely weathered) based on certain parameters such as color changes, strength index, rocks-soils ratio (RSR) and micro-index (micro-petrography, $\mathrm{I}_{\mathrm{mp}}$, and micro-fractures, $\mathrm{I}_{\mathrm{fr}}$, index) [1]. Higher rocks exposure to weathering processes may cause changes in rock microfabrics such as the decrement of percentage of primary minerals, secondary mineral formation, the presence of pores and microfractures which provide failure planes and collision to occur. Microfabric observation measured with scale of $100-1$ $\mu \mathrm{m}$ and magnification up to 8000 times is seen important to observe inner changes occurred in rocks on different weathering grade. However, different types of rocks have different microfabrics [2]. Aspects such as texture and particle orientation, mineral composition and microstructure in rocks are varied which depends on the types of rocks and its formation processes. The breakdown between mineral bonds and microfractures formation can reduce the strength of rocks [3]. This is influenced by weathering process that plays role in widening the microfractures in addition to clay mineral formation in particular rocks material. This condition led to more porous and weak due to the disturbed interparticle bond which include the formation of intra- and interparticle microfractures, clay mineral layered structure and loose granule arrangement structure, whereas, less porous rocks with solid and fine texture will resulted in higher strength [4-7].

The increment of porosity value and reduction of density is along throughout the weathering grade, where the moisture content, porosity and density influenced the strength value of rocks from Crocker and Trusmadi Formation with $2.44-0.33 \mathrm{MPa}$ and $4.73-0.69 \mathrm{MPa}$ respectively [8]. Peridotite in the study area also produced more microfractures and significant formation of clay minerals on higher weathering grade. The bigger the aperture of the fractures, water intrusion rate is higher and able to accelerate the weathering process since water plays as one of the weathering agent. Therefore, this study is carried out to see the effect of the weathering process on the microfabrics of various types of rocks in Ranau, Sabah which affect its mechanical properties.

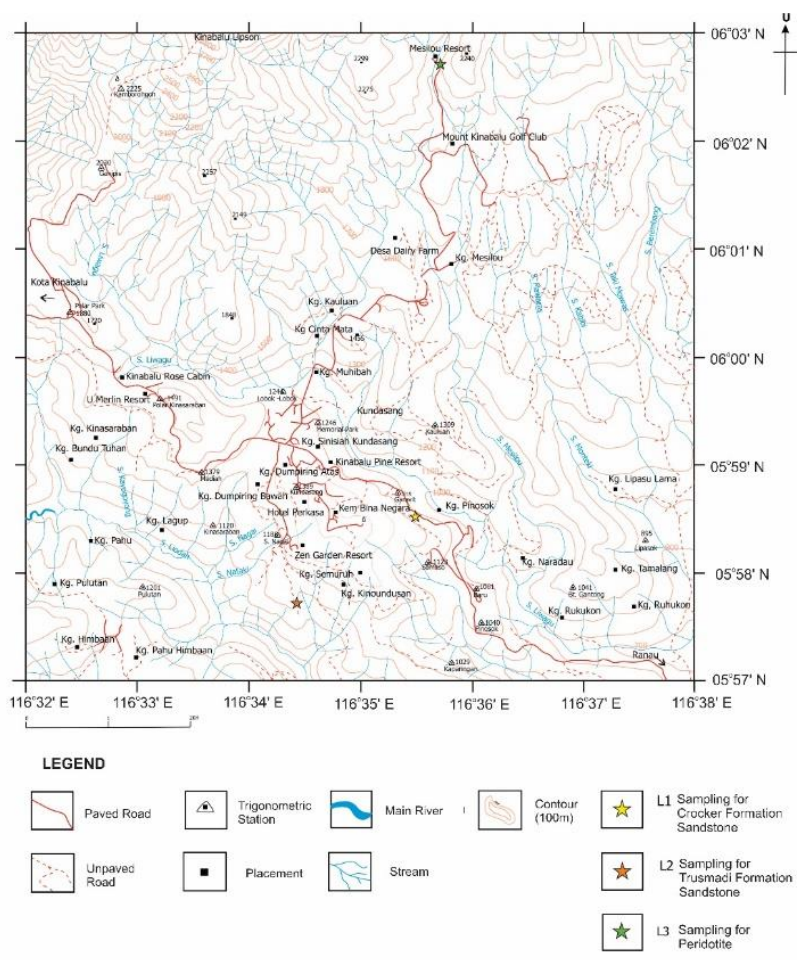

Figure 1: Base map and sampling localities of the study area in Ranau, Sabah

The study area is located at Ranau district, Sabah bounded by $05^{\circ} 52^{\prime} \mathrm{N}-$ $06^{\circ} 03^{\prime} \mathrm{N}$ and $116^{\circ} 32^{\prime} \mathrm{E}-116^{\circ} 38^{\prime} \mathrm{E}$ (Figure 1). It consists of four types of rock units namely Pinosouk Gravel aged Pleistocene, Crocker Formation (Late Eocene - Early Miocene), Trusmadi Formation (Early Miocene) and serpentinized peridotite aged Cretaceous. Trusmadi Formation is divided 
into four main units of argillite, turbidite, cataclastic and massive sandstones while the younger Crocker Formation shows the presence of thick sandstones, interbedded of sandstone and shale on the same thickness and shale units [9]. The study area received rainfall distribution with average of $2800 \mathrm{~mm}$ per year and temperature of $26-28^{\circ} \mathrm{C}$. This condition has allowed the weathering process to act intensively in the study area and different type of rocks exhibited different endurance of weathering process even it was in the same surrounding.

\section{MATERIALS AND METHODOLOGY}

Base map and geological map were produced before beginning the fieldworks. Base map provides geographical information meanwhile the geological map shows the distribution of rocks units in the study area. Fieldworks are carried out to obtain detailed information on the study area which includes the geomorphological study such as weathering processes, erosion and mass movements that took place in the study area. Samples of sandstones from Crocker and Trusmadi Formation and peridotite were collected from weathering grade II to $\mathrm{V}$ based in the ration of rocks and soil, primary mineral changes index, microfractures index and the spacing of fractures [3]. Grade II showed closed joints with minor color changes; while the opening will increase and filled with clay minerals in Grade III. In highly weathered rocks (Grade IV), the joint opening increased and the spacing decreased with clay was the common filling. Whereas, Grade V showed nearly $90 \%$ of the material were completely weathered with rock texture is partly preserved but the grains have been completely separated.

For engineering properties purpose, analyses carried out were based on International Standard of Rock Mechanics (ISRM) and American Society Testing Method (ASTM) [10,11]. Every rock samples of different weathering grade will undergo the same analysis. Analysis of physical properties of rocks include moisture content analysis (moisture is measured after $105^{\circ} \mathrm{C}$ dried oven), density analysis (mass over rock volume in cubic form of $3 \mathrm{~cm} \times 3 \mathrm{~cm}$ to determine the weight of material to the bulk density of the rock), porosity analysis (to determine the percentage of pores through gridding or point counting method) and slake durability analysis (where 10 pieces of rocks with average of $40-60$ grams per piece were prepared and is allowed to rotate at $200 \mathrm{rpm}$ for 10 minutes to test its resistance on weathering). Rock hardness analysis is carried out in-situ by using Schmidt hammer by placing it perpendicularly on the flat rock's surface [12]. Meanwhile, point load test was conducted to determine the strength of the samples which have been cut into cubic size and placed between two vertical cones before the stress is applied. The classification of the strength is based on ISRM (Table 1) [13].

Table 1: Classification of rock strength [13].

\begin{tabular}{|c|c|c|}
\hline Classification & Is $_{\mathbf{5 0}}$ (MPa) & Equivalent UCS (MPa) \\
\hline Extremely Weak & \multirow{2}{*}{$\begin{array}{c}\text { Generally do } \\
\text { not applies }\end{array}$} & $0.5-1.25$ \\
\cline { 1 - 1 } \cline { 3 - 3 } Very Weak & $0.2-0.5$ & $1.25-5.0$ \\
\hline Weak & $\begin{array}{c}\text { Moderately } \\
\text { Weak }\end{array}$ & $5.0-12.5$ \\
\hline $\begin{array}{c}\text { Moderately } \\
\text { Strong }\end{array}$ & $0.5-2.0$ & $12.5-50$ \\
\hline Strong & $2.0-4.0$ & $50-100$ \\
\hline Very Strong & $4.0-8.0$ & $100-200$ \\
\hline Extremely Strong & $>8.0$ & $>200$ \\
\hline
\end{tabular}

As for the microfabric observation, X-ray diffraction analysis (XRD) analysis is carried out to study the type of clay minerals present based on the information of mineral's crystal structure. In addition, all samples must undergo petrographic analysis where samples were cut and polished into $0.03 \mathrm{~mm}$ thickness using $300-1000$ mesh corundum powder. This analysis is conducted using polarized light microscope model Carl Zeiss to determine the presence of minerals and microstructures [14]. The microfabric observation also include SEM analysis where scanning electron microscope model Phillips XL40 with 60 psi pressure and 15 - 20 $\mathrm{kV}$ voltages were used to see the changes of primary minerals, the appearance of secondary minerals and microstructure (pore spaces, microfractures, size and shape of the particles) from weathering grade II to $\mathrm{V}$. All data obtained either quantitative of qualitative will be discussed in detail based on the type of rocks.

\section{RESULTS AND DISCUSSIONS}

Table 2 to 4 show the results of laboratory analysis which have been conducted on all rock samples, whereas Figure 2 to 7 show the microfabric observation on sandstones of Crocker Formation, sandstones of Trusmadi Formation and peridotite, respectively, throughout weathering grade II to

\subsection{Microfabric Observation}

\subsubsection{Crocker Formation}

Figure 2 showed the photomicrographs of sandstones from Crocker Formation throughout weathering grade II to V. The samples showed dominance of euhedral-shaped quartz with intermediate texture of coarse and fine grains in Grade II (Photo A). The matrix filled in the spaces between the particles with small aperture among particles [15]. Along the weathering, the formation of intraparticles microfractures on monocrystallize quartz showed distinct cracks (Photo B) which allowed the edges to erode resulted to rounder shape of quartz mineral (Photo $\mathrm{C}$ ). The samples showed smaller size of monocrystallize quartz due to presence of microfractures with a good amount of lithic and matrix (Photo D). Based on XRD analysis, the samples from Crocker Formation showed the presence of quartz, albite and muscovite on Grade II and the appearance of clay mineral illite on Grade V.
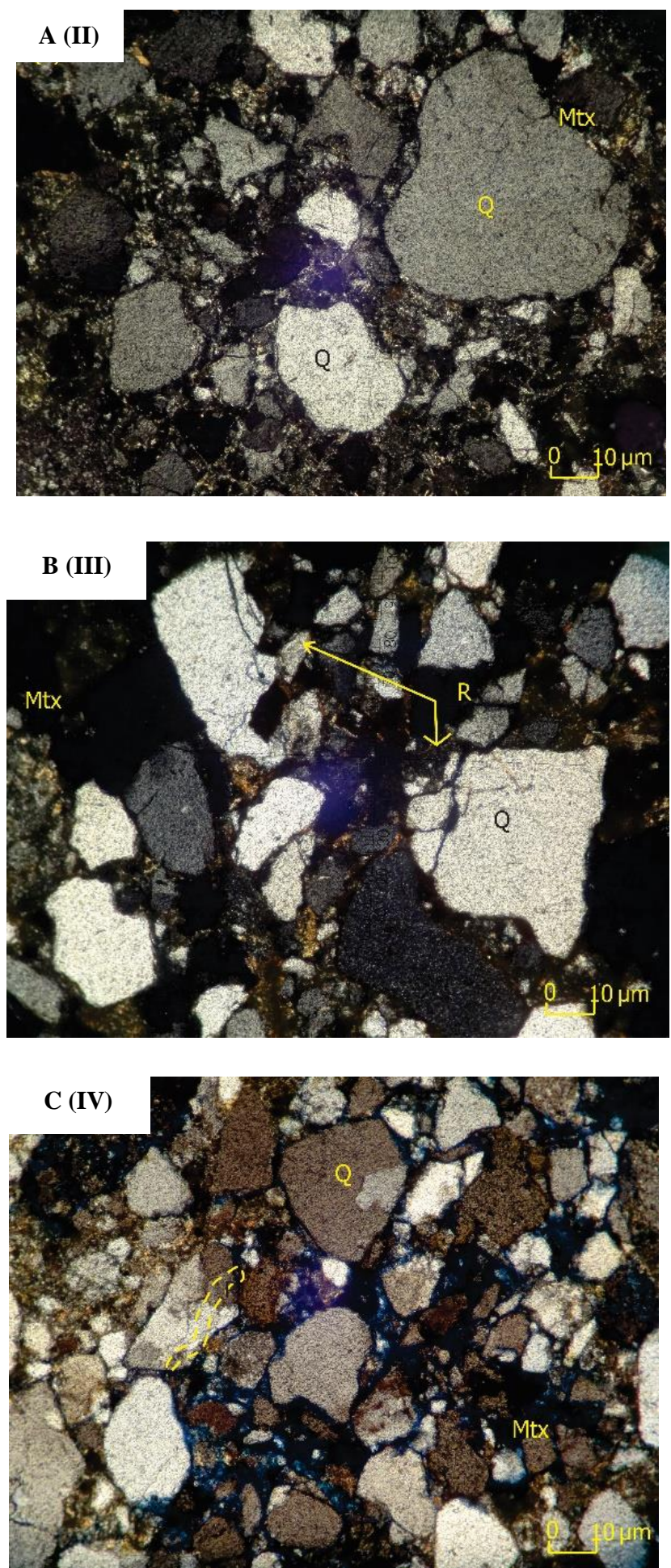


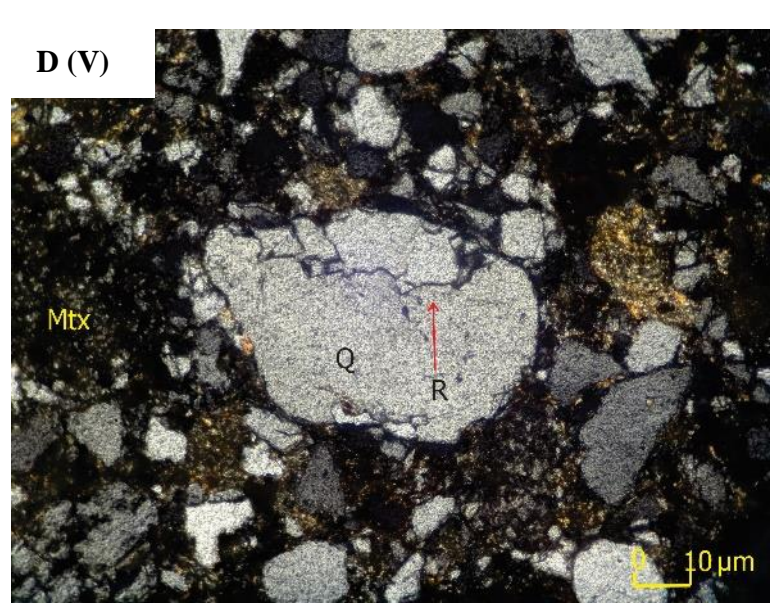

Figure 2: Photomicrographs showed the microfabric changes of samples from Crocker Formation throughout weathering grade
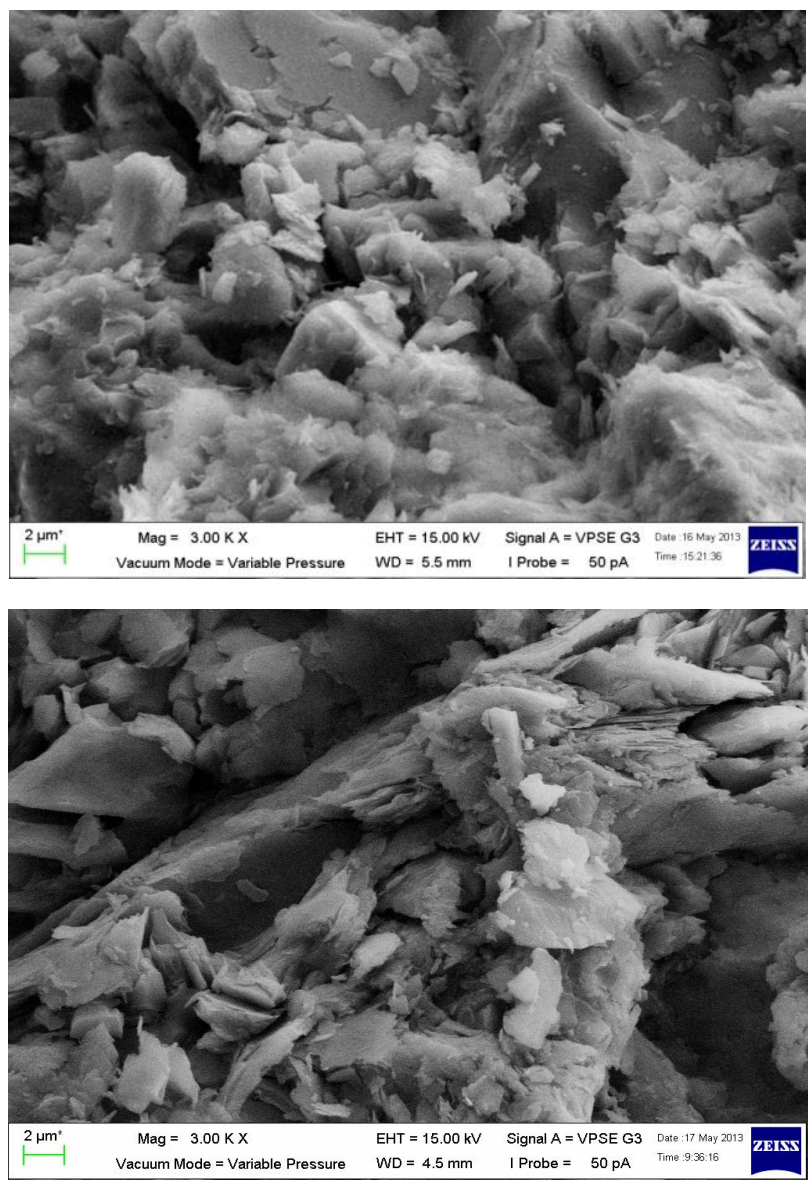

Figure 3: $\quad$ SEM microphotographs showed the presence of quartz on Grade II (left photo) and the appearance of clay mineral illite on Grade V (right photo) (Magnification 3000X)

\subsubsection{Trusmadi Formation}

Figure 4 showed photomicrographs of sandstones from Trusmadi Formation throughout weathering grade II to V. On Grade II, the grains arrangement is packed with dominance of coarse-size quartz mineral with small amount of matrix (Photo A). Microfractures started to form intraparticle and the edges of quartz begin to erode (Photo B) thus loosen the grain arrangement (Photo C) along the weathering process [16]. Porosity increased due to dissolution of unstable minerals and rapid formation of microcracks. Some of the voids were filled by clay minerals that presence on Grade V (Photo D). XRD analysis showed the dominance of quartz with the presence of biotite, plagioclase and anortite other than clay minerals formation such as kaolinite, illite and montmorillonite on Grade V. Figure 5 showed the SEM photomicrographs of samples from Trusmadi Formation which exhibited the presence of quartz on Grade II and clay minerals during Grade V.
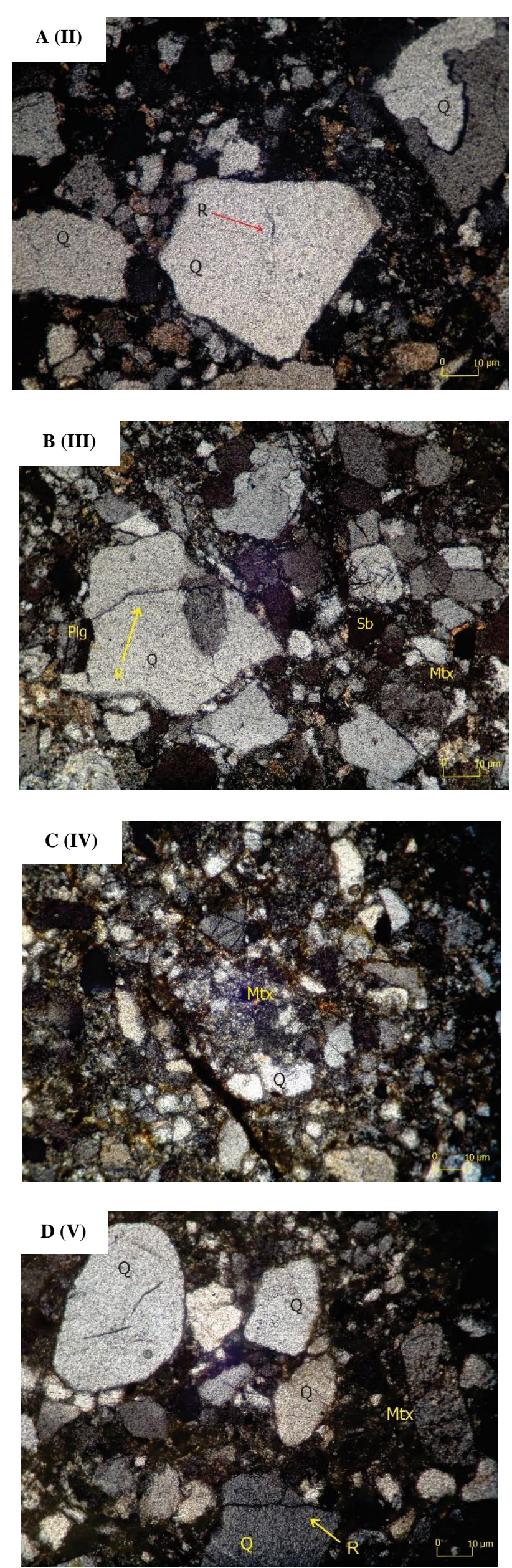

Figure 4: Photomicrographs showed the microfabric changes of samples from Trusmadi Formation throughout weathering grade II to V (Photo A - D) (Magnification 10X, XPL) 

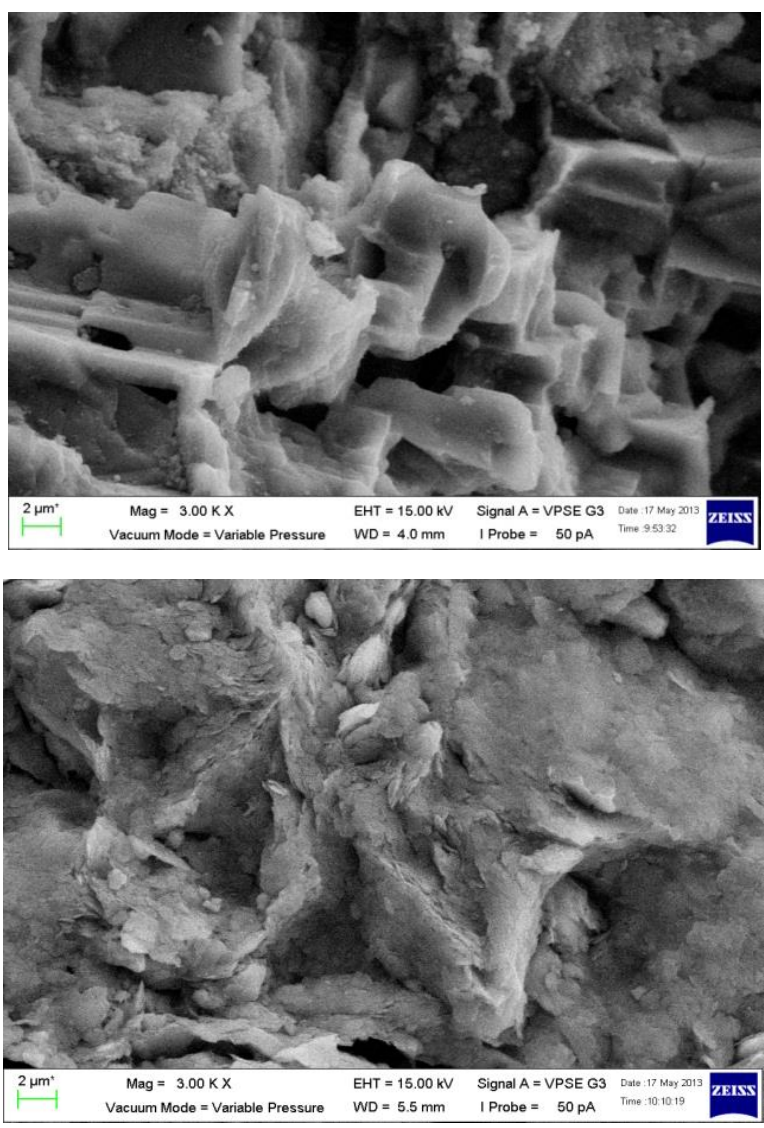

Figure 5: SEM microphotographs showed the presence of euhedral quartz on Grade II (left photo) and the appearance of clay

\subsubsection{Peridotite}

Based on petrography analysis, peridotite sample was classified as harzburgite with $75 \%$ of olivine, $22 \%$ orthopyroxene and $3 \%$ clinopyroxene. Figure 6 showed the packed arrangement with small pores resulted to strong bonding between minerals on Grade II (Photo A). Microfractures begin to form and increase the porosity in the samples (Photo B and C). On Grade V, the grain arrangement begins to less pack due to bigger aperture of the microcracks (Photo D). Significant interparticle microfractures had breakdown the minerals into smaller size which affect to its failure plane formation. XRD analysis showed the dominance of olivine and orthopyroxene in peridotite samples in the study area. Figure 7 showed SEM photomicrographs of peridotite where cleavage minerals were clearly observed on Grade V resulted to its failure and weak point.

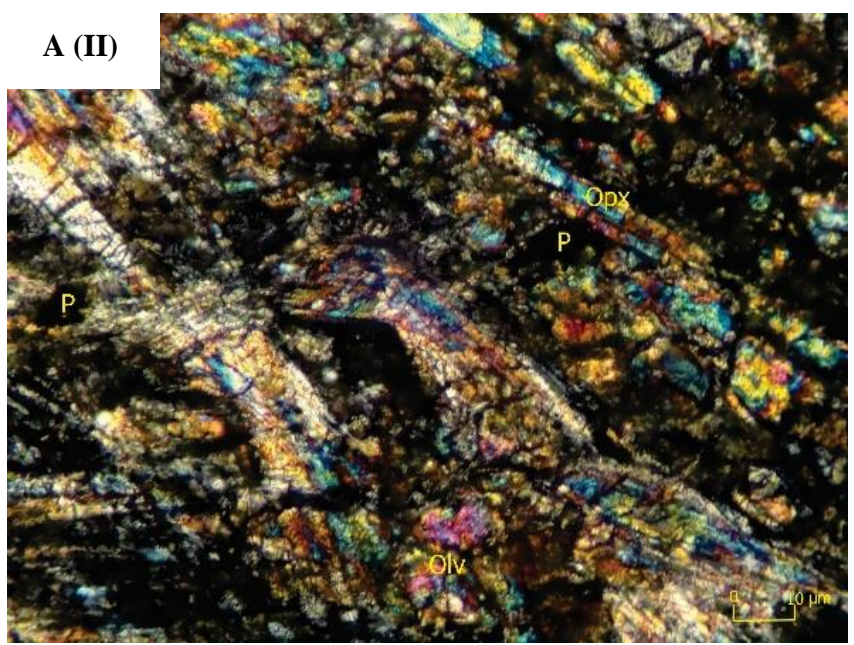

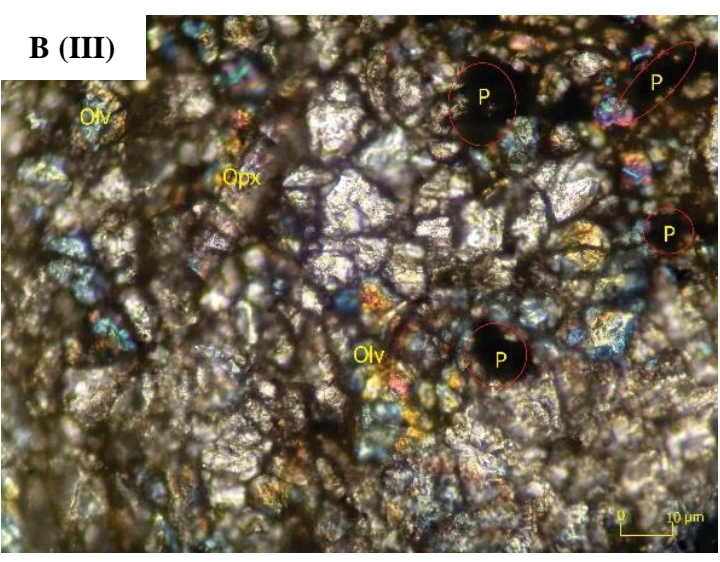
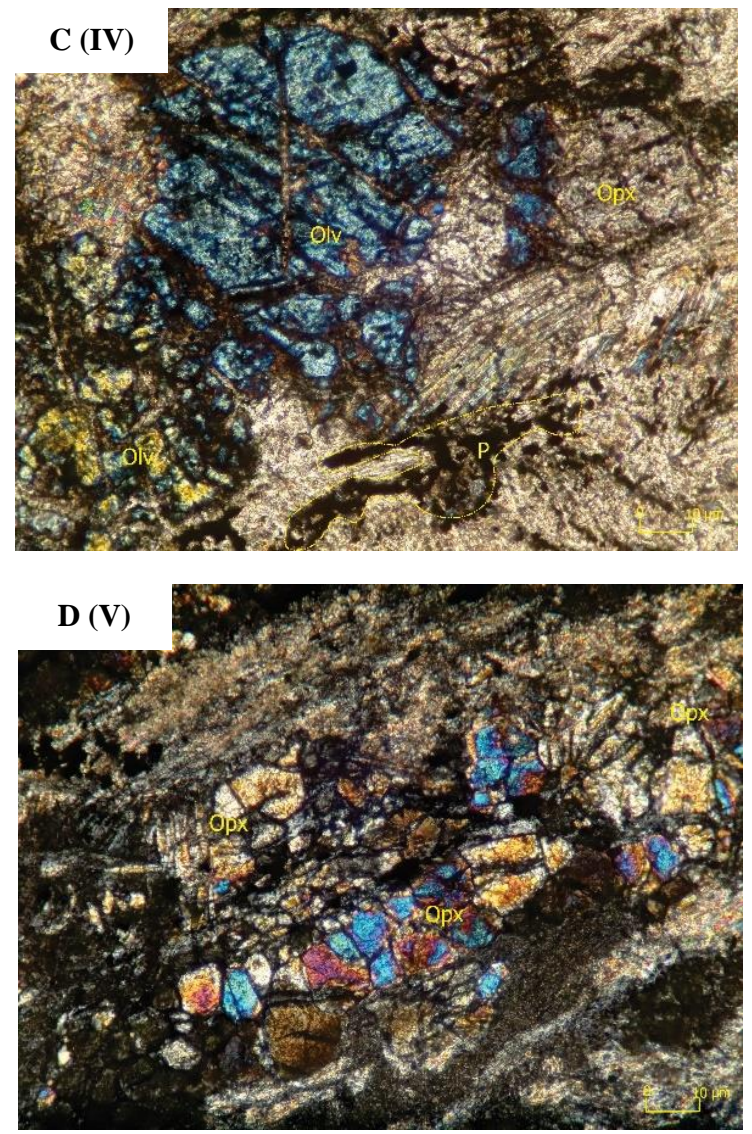

Figure 6: Photomicrographs showed the microfabric changes of peridotite throughout weathering grade II to V (Photo A - D)

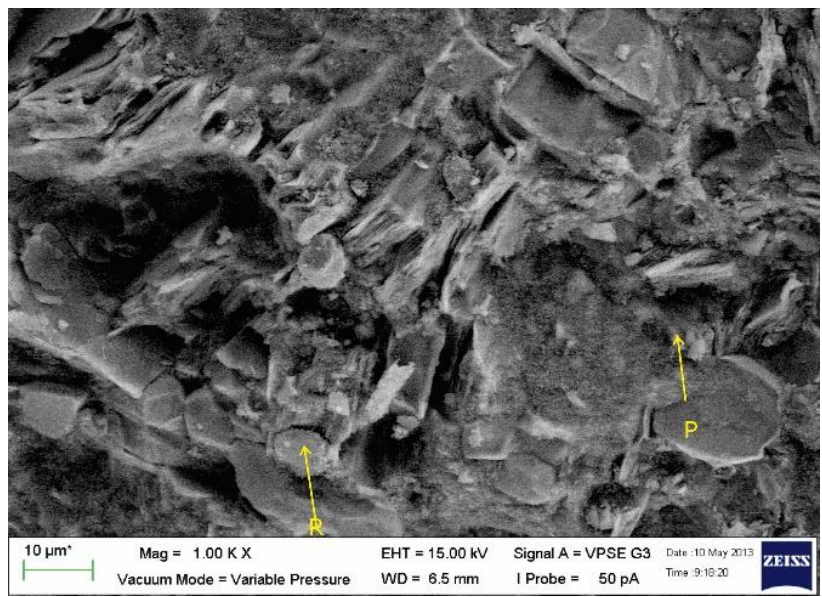




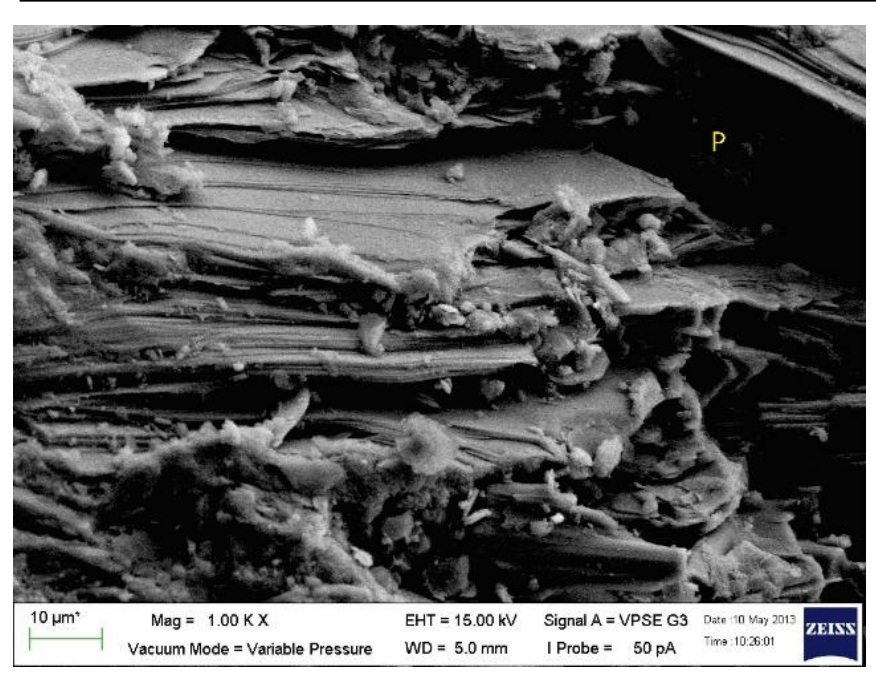

Figure 7: SEM microphotographs showed the presence of cleavage in peridotite. The crystal structure of minerals allowed

\subsubsection{Mechanical Properties of Rock Samples}

Table 2 to 4 below showed the mechanical properties that been conducted on all samples. Samples from Crocker Formation showed higher moisture content (3.15 - 3.43\%) compared to samples from Trusmadi Formation $(0.33-1.62 \%)$ and peridotite $(0.47-0.93 \%)$ throughout weathering grade II to V. This was due to higher percentage of porosity in samples from Crocker Formation which also resulted to less dense rocks. Density decreased along the weathering process where peridotite showed the densest due to its mineral composition such as olivine-dominance and packed texture. All samples were classified from very strong to strong on Grade II with samples from Trusmadi Formation stated the highest with 187.06 MPa followed by peridotite (125.27 MPa) and Crocker Formation (83.15 MPa). With the increment of weathering grade, the strength is reduced where Crocker Formation showed significant decrement from moderately strong to extremely weak from Grade III to V with $22.35-0.43$ MPa.

Table 2: Mechanical properties values of Crocker Formation from Grade II - V

\begin{tabular}{|c|c|c|c|c|c|c|c|}
\hline $\begin{array}{c}\text { CROC } \\
\text { KER } \\
\text { Fm. }\end{array}$ & $\begin{array}{c}\text { Moist } \\
\text { ure } \\
\text { Cont } \\
\text { ent } \\
(\%) \\
\end{array}$ & $\begin{array}{l}\text { Den } \\
\text { sity } \\
(\mathrm{g} / \mathrm{c} \\
\left.\mathrm{m}^{3}\right)\end{array}$ & $\begin{array}{c}\text { Poro } \\
\text { sity } \\
(\%)\end{array}$ & $\begin{array}{c}\text { Slake } \\
\text { Durab } \\
\text { ility } \\
(\%)\end{array}$ & $\begin{array}{c}\text { Hard } \\
\text { ness } \\
\text { (MPa } \\
\text { ) }\end{array}$ & $\begin{array}{c}\text { Stre } \\
\text { ngth } \\
\text { (MPa } \\
\text { ) }\end{array}$ & $\begin{array}{c}\begin{array}{c}\text { Classific } \\
\text { ation } \\
\text { (ISRM, } \\
1985 \text { ) }\end{array}\end{array}$ \\
\hline II & 3.15 & 2.69 & $\begin{array}{c}11.1 \\
2\end{array}$ & 90.02 & 38 & $\begin{array}{c}83.1 \\
5\end{array}$ & Strong \\
\hline III & 3.17 & 2.39 & $\begin{array}{c}15.7 \\
9\end{array}$ & 89.09 & 25 & $\begin{array}{c}22.3 \\
5\end{array}$ & $\begin{array}{c}\text { Modera } \\
\text { tely } \\
\text { Strong }\end{array}$ \\
\hline IV & 3.18 & 2.34 & $\begin{array}{c}20.1 \\
3\end{array}$ & 91.14 & 20 & 8.23 & $\begin{array}{c}\text { Modera } \\
\text { tely } \\
\text { Weak }\end{array}$ \\
\hline V & 3.43 & 2.01 & $\begin{array}{c}25.6 \\
7\end{array}$ & 72.63 & 13 & 0.43 & $\begin{array}{c}\text { Extrem } \\
\text { ely } \\
\text { Weak }\end{array}$ \\
\hline
\end{tabular}

Table 3: Mechanical properties values of Trusmadi Formation from Grade II - V

\begin{tabular}{|c|c|c|c|c|c|c|c|}
\hline $\begin{array}{c}\text { TRUS } \\
\text { MADI } \\
\text { Fm. }\end{array}$ & $\begin{array}{c}\text { Mois } \\
\text { ture } \\
\begin{array}{c}\text { Cont } \\
\text { ent } \\
(\%)\end{array}\end{array}$ & $\begin{array}{c}\text { Den } \\
\text { sity } \\
(\mathrm{g} / \mathrm{c} \\
\left.\mathrm{m}^{3}\right)\end{array}$ & $\begin{array}{c}\text { Poro } \\
\text { sity } \\
(\%)\end{array}$ & $\begin{array}{c}\text { Slake } \\
\text { Dura } \\
\text { bility } \\
(\%)\end{array}$ & $\begin{array}{c}\text { Hard } \\
\text { ness } \\
\text { (MPa } \\
)\end{array}$ & $\begin{array}{c}\text { Stre } \\
\text { ngth } \\
\text { (MP } \\
\text { a) }\end{array}$ & $\begin{array}{c}\text { Classifi } \\
\text { cation } \\
\text { (ISRM, } \\
1985)\end{array}$ \\
\hline II & 0.33 & 3.19 & 9.65 & 99.33 & 140 & $\begin{array}{c}187 . \\
06\end{array}$ & $\begin{array}{c}\text { Very } \\
\text { Strong }\end{array}$ \\
\hline III & 0.87 & 2.90 & $\begin{array}{c}12.8 \\
9\end{array}$ & 98.96 & 45 & $\begin{array}{c}95.5 \\
2\end{array}$ & Strong \\
\hline IV & 1.07 & 2.80 & $\begin{array}{c}16.7 \\
8\end{array}$ & 97.32 & 40 & $\begin{array}{c}43.5 \\
8\end{array}$ & $\begin{array}{c}\text { Moder } \\
\text { ately } \\
\text { Strong }\end{array}$ \\
\hline
\end{tabular}

\begin{tabular}{|c|c|c|c|c|c|c|c|}
\hline $\mathbf{V}$ & 1.62 & 2.30 & $\begin{array}{c}18.9 \\
9\end{array}$ & 92.91 & 25 & 2.48 & Weak \\
\hline
\end{tabular}

Table 4: Mechanical properties values of peridotite from Grade II - V

\begin{tabular}{|c|c|c|c|c|c|c|c|}
\hline $\begin{array}{c}\text { PERID } \\
\text { OTITE }\end{array}$ & $\begin{array}{c}\text { Moist } \\
\text { ure } \\
\begin{array}{c}\text { fonte } \\
\text { nt } \\
(\%)\end{array}\end{array}$ & $\begin{array}{c}\text { Den } \\
\text { sity } \\
(\mathrm{g} / \mathrm{c} \\
\left.\mathrm{m}^{3}\right)\end{array}$ & $\begin{array}{c}\text { Po } \\
\text { ros } \\
\text { ity } \\
(\%\end{array}$ & $\begin{array}{c}\text { Slake } \\
\text { Durab } \\
\text { ility } \\
(\%)\end{array}$ & $\begin{array}{c}\text { Har } \\
\text { dne } \\
\text { ss } \\
(\mathrm{MP} \\
\text { a) }\end{array}$ & $\begin{array}{c}\text { Stre } \\
\text { ngt } \\
\text { h } \\
(\mathrm{MP} \\
\text { a) }\end{array}$ & $\begin{array}{c}\text { Classific } \\
\text { ation } \\
\text { (ISRM, } \\
1985)\end{array}$ \\
\hline II & 0.47 & 3.31 & $\begin{array}{c}4.3 \\
8\end{array}$ & 98.72 & 45 & $\begin{array}{c}125 \\
.27\end{array}$ & $\begin{array}{c}\text { Very } \\
\text { Strong }\end{array}$ \\
\hline III & 0.56 & 3.14 & $\begin{array}{c}5.4 \\
4\end{array}$ & 98.66 & 40 & $\begin{array}{c}95 . \\
52\end{array}$ & Strong \\
\hline IV & 0.81 & 2.90 & $\begin{array}{c}8.7 \\
8\end{array}$ & 98.67 & 32 & $\begin{array}{c}38 . \\
43\end{array}$ & $\begin{array}{c}\text { Moderat } \\
\text { ely } \\
\text { Strong }\end{array}$ \\
\hline $\mathbf{V}$ & 0.93 & 2.50 & $\begin{array}{c}10 . \\
56\end{array}$ & 98.42 & 21 & $\begin{array}{c}20 . \\
92\end{array}$ & $\begin{array}{c}\text { Moderat } \\
\text { ely } \\
\text { Strong }\end{array}$ \\
\hline
\end{tabular}

\subsubsection{Relationship between Mechanical Properties and Rock's Strength}

Figure 8 showed the relationship between mechanical properties of rocks with the rock's strength. With the increment of weathering grade, some of primary minerals were dissolved and microfractures were formed thus resulted to the addition of porosity in the rock mass. These pores contributed to lower density and increased the moisture content, which aid to the collision and slide among particles therefore reduced the hardness and strength of the rocks when the weathering grade is increased.

High moisture content contributed to low rock's strength due to pores and fractures that formed during weathering which allows the moisture to trap in [17]. In addition, the presence of clay minerals which are able to adsorb moisture also resulted to decrement of its strength (Figure 8A). The increment of weathering grade produced more pores which reduced the rock's strength) (Figure 8B). This led to lower density (Figure 8C). All these properties also affect to its hardness where the rock samples showed significant reduction of hardness when the weathering grade is higher due to less strength and dominated microcracks (Figure 8D).
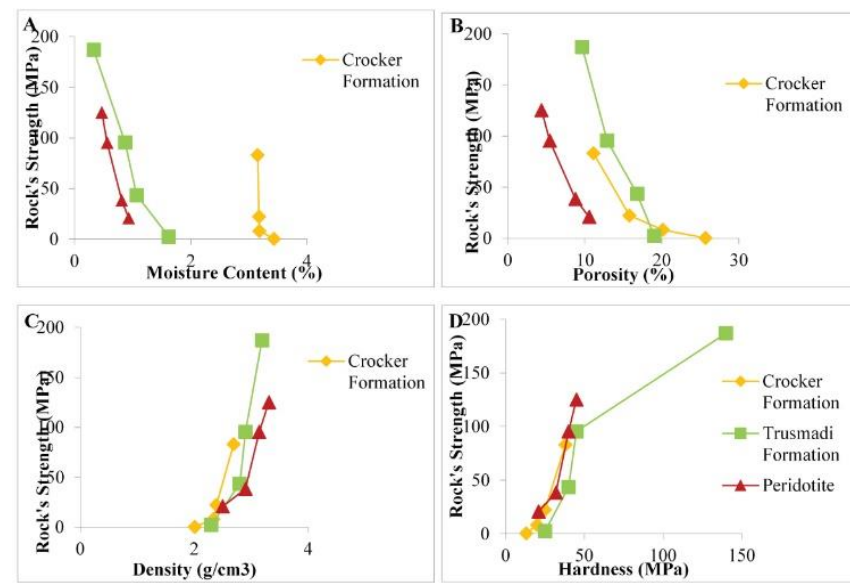

Microfabric index will increase throughout weathering grade II to V. All samples showed the increment of porosity and the decrement of density, hardness and strength when the weathering grade increased. All rock samples will easily fail on Grade $V$ due to microfractures formation other than primary minerals alteration to clay formation which resulted to failure plane and collision between particles. By understanding this, it is easier to predict and estimate the strength of rock slope and slope failure occurrences. Rock samples from Trusmadi Formation showed higher strength properties due to the presence of quartz which has higher friction angle than Crocker Formation with 187.06-2.48 MPa and 83.15 - 0.43 MPa respectively. The interlocking bond between particles in Trusmadi Formation also contributed to its significant strength compared to peridotite which exhibited more fractures due to the appearance of cleavage-like minerals.

\section{ACKNOWLEDGEMENT}

The author would like to express special gratitude to Ms. Noraziela Nolhak and Ms. Lenny Lau for sampling and preparation for this research.

\section{REFERENCES}


[1] Brand, E.W. 1990. Proceedings of 2nd International Conference on Geomechanics in Tropical Soils, 515-518.

[2] Hennie Fitria Wulandary Soehady Erfen. 2009. Penilaian mikrofabrik dan Sifat Kekuatan Bahan Batuan Volkanik dan Batu Pasir Terluluhawa, Tawau, Sabah. Disertasi Sarjana Sains. UMS.

[3] Beavis, F.C. 1985. Geologi Kejuruteraan. Ibrahim Komoo and Tajul Anuar Jamaluddin (ptjr) 1002. Dewan Bahasa dan Pustaka.

[4] Anon. 1995. Geophysical Surveys in Archaelogical Field Evolution. English Heritage and Profesional Service Guide.

[5] Ogilvie, S.R. and Glover, P.W.J. 2001. The Petrophysical Properties of Deformation Bands in Relation to their Microstructure. Earth and Planetary Science Letters, 193, 129-142.

[6] Sun, S., Shu, L, Zeng, Y, Cao, J. and Feng, Z. 2006. PorosityPermeability and Texturak Heterogeneity of Reservoir Sandstone from Lower Cretaceous Putaohua Member of Yaojia Formation, Northeast China. Marine and Petroleum Geology.

[7] Hatzor, V.H., and Palchik, V. 1998. A Microstructure based Failure Criterion for Aminadar Dolomites. International Journal of Rock Mechanics and Mining Services, 35, 797-805.

[8] Ali, M.S. 2011. Geologi Am dan Penilaian Mikrofabrik Batuan Terluluhawa dari Formasi Crocker dan Formasi Trusmadi di Ranau, Sabah. Disertasi Sarjana Muda Sains. UMS.
[9] Tongkul, F. 1987. Structural Style and Tectonics of Western and Northern Sabah. Bulletin of the Geological Society of Malaysia, 27, 227 239.

[10] International Standard of Rock Mechanics. 1979. International Journal Rock Mechanic Mining Science and Geomechanics, 16.

[11] American Society for Testing Materials. 2000. Unconfined Compressive Strength of Cohesive Soil.

[12] Atkinson, J.H. 1978. Mekanik Tanah:Pengenalan Mekanik Tanah Peringkat Genting. Rosiyah And. Latif (ptrjr) 1991. Dewan Bahasa dan Pustaka.

[13] International Society of Rock Mechanics. 1985. International Journal of Rock Mechanic, Mining Science and Geomechanics, 22, 51-60.

[14] Fookes, P.G., Dearclan, W.R. and Franklin, I.A. 1971. Some Engineering Aspects of Rock Weathering. Quaterly Journal of Engineering Geology,4 (3), DOI: 10.1144/GSL.QJEG.1971.004.03.01

[15] Hancock, P.L. 1989. Current Topics in Structural Geology. Pergamon Pres, $238 \mathrm{pp}$.

[16] Ramamurthy, T. 2010. Engineering in Rocks for Slope, Foundation and Tunnels. New Delhi.

[17] McLean, A.C., and Gribble, C.D. 1979. Geology for Civil Engineers. London. 